\title{
Performance evaluation of biosimulator for treating domestic wastewater using activated sludge treatment system
}

\author{
HASHMI IMRAN
}

Institute of Environmental Science and Engineering, National University of Sciences and Technology, Tamiz uddin Road, Rawalpindi, Pakistan

\begin{abstract}
This research investigation was aimed at demonstrating the performance evaluation of pilot activated sludge treatment system (biosimulator; model MF-114). An intensive analytical program was followed for evaluating the performance efficiency of the biosimulator by maintaining the dissolved oxygen (DO) concentration at $4.0 \mathrm{mg} / \mathrm{L}$ throughout the study period. Biosimulator performance was evaluated after every 2 hours and analyzed for $\mathrm{pH}, \mathrm{DO}, \mathrm{COD}$, ammonia-nitrogen $\left(\mathrm{NH}_{3}-\mathrm{N}\right)$, nitrite-nitrogen $\left(\mathrm{NO}_{2}-\mathrm{N}\right)$ and nitrate-nitrogen $\left(\mathrm{NO}_{3}-\mathrm{N}\right)$. In all ten experimental replicates were performed and the mean figures are taken for discussion. Although no significant variation in the $\mathrm{pH}$ was observed during the study period but the mean $\mathrm{pH}$ values of the samples during the treatment process gradually increased and it ranged from 6.81-7.52. The removal of COD was found to be in direct relationship with retention time and the mean COD of the raw wastewater samples ranged from 164-1160 mg/L whereas it got reduced considerably during the treatment process and the mean removal efficiency was found to be $86 \%$. The COD and $\mathrm{NO}_{2}-\mathrm{N}$ removal efficiency was better than $\mathrm{NH}_{3}-\mathrm{N}$ and $\mathrm{NO}_{3}-\mathrm{N}$ this is considered to be satisfactory especially with respect to organic loading and retention time. Similarly, the mean $\mathrm{NH}_{3}-\mathrm{N}$ values of wastewater after 29 hours of treatment were found to be fluctuating between 14.52-20.54 mg/L whereas the mean $\mathrm{NO}_{3}-\mathrm{N}$ level of the raw wastewater ranged from $0.106-0.279 \mathrm{mg} / \mathrm{L}$. The overall conditions were very much favorable even at high organic loading and minimum retention time. It is therefore concluded that the system is practically feasible for the treatment of wastewater containing high content of organic matter. @JASEM
\end{abstract}

Environmental pollution develops and deepens whenever the volume of wastewater flow exceeds combined capacity of natural and manmade facilities organized to control, capture, convoy and decompose the generated waste. The industrial or domestic wastewater discharged untreated into aquatic environment results in serious water pollution, causing deterioration of marine environment (WRIR, 1990; Nicholas, 1989).

The ecology of the activated sludge system is very complex and dynamic. It represents a very complicated and variable biological activity depending upon temperature, $\mathrm{pH}, \mathrm{DO}$ level, etc. Heterotrophs and autotrophs influence nitrogen and carbon removal during the wastewater treatment. The activated sludge process has been utilized since long time for the treatment of domestic and industrial wastewater; it is quite efficient in decreasing the concentration of many priority pollutants to concentrations below detection and permissible limits (Ramalho, 1997; Robert, 1998). The principle of the system is based upon the aeration of the wastewater, which reduces the organic matter and finally produces a flocculent sludge. The sludge contains some inert solids, but the main components making up its loose, flocculent structure are living or active bacteria and protozoa, hence the name activated sludge (Mara, 1978). Muller et al., (1980) observed the removal of volatile non-biodegradable organic compounds from wastewater during the activated sludge treatment. One of the reliable and accurate estimates of these biodegradable organic compounds is the chemical oxygen demand. The COD method is a rigorous, high temperature, acidic, chemical digestion process in which oxygen demanding materials are consumed by a powerful oxidizing agent (Standard Methods, 1985). The treatment of domestic wastewater during the treatment produced the water of good quality and there is an interest in its potential for drinking water supply (McCartey et al., 1984). The domestic wastewater contains readily biodegradable organic matter which is mainly composed of volatile fatty acids and low molecular weight carbohydrates that can pass through the cell membrane and be metabolized within minutes by the bacteria (Henze et al., 1987). It has been reported that microorganisms that bring about the decomposition of organic matter in wastewater can perform their activity efficiently in the activated sludge system (Barker and Dold, 1995). Eliosov and Argaman (1995) observed the hydrolysis of particulate organic matter in activated sludge system and reported that the degradation rate of the particulate matter in raw domestic wastewater was slower than that of nonsettleable particulate matter, which was due to the physical characteristics of two types of particles. Filamentous microorganisms affect the sludge settling. It is reported that a high filament length concentration, zone settling velocity reaches a maximum value and the decrease with increasing suspended solid concentration (Sezgin, 1980). The sludge age together with mixed liquor suspended solids in the aeration tank generates the dynamic stability of the overall process. An under loaded and over loaded system can lead the whole process dynamically unstable (Cakici and Bayramoglu, 1995). Figure 1 shows the arrangements of the

Author for correspondence: Phone 92-(051)9271598 Ext: 114; Fax 92-(051)9271597;

E-mail: hashmi71@gmail.com) 
various functional units of the wastewater treatment plant.

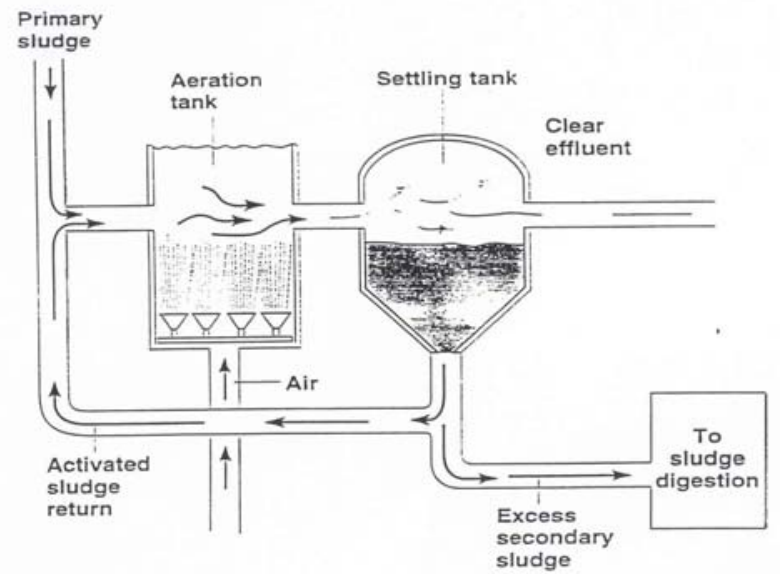

Fig 1. Sludge treatment system

In wastewater ammonia is produced by the hydrolysis of urea and by biological degradation of organic compounds. Ammonia is found in equilibrium between the molecular gaseous form and the ionic form. The reaction is highly dependent on $\mathrm{pH}$. Alkaline $\mathrm{pH}$ favors the molecular forms whereas the neutral and acidic $\mathrm{pH}$ favors the presence of ionic forms. Ammonia loss is found to be more pronounced at $\mathrm{pH}$ 8-9. In the present study the residual $\mathrm{NH}_{3}-\mathrm{N}$ was still very high which may be due to neutral range of $\mathrm{pH}$. The nitrifying bacteria such as Nitrosomonas and Nitrobacter being slow growing organisms may not be retained for short sludge age of 2-5 days (Lumbers, 1984). The microbial activity converts the organic nitrogen into ammonia and ammonium. Ammonia is found in equilibrium between the molecular gaseous form and the ionic form. The reaction is highly dependent on $\mathrm{pH}$ and temperature. Alkaline $\mathrm{pH}$ and higher temperature favor the molecular forms whereas neutral and acidic $\mathrm{pH}$, favor the presence of ionic forms. The transfer of ammonia from liquid to the atmosphere occurs when the partial pressure of dissolved gases in the water is greater than that of the gas in the atmosphere near the air liquid interface until equilibrium of partial pressure is achieved (Idelovitch and Michail, 1981). The ammonium ions in turn are nitrified to nitrite and then nitrate. Two transient intermediates are involved in the nitrification; hydroxylamine and hypothetical nitrogen form. The metastable nitrite is seldom found and the final end product of nitrification is nitrate (Alleman and Irvine, 1980). The nitrate and a portion of ammonium are used for the synthesis of cellular protein and other nitrogenous compounds of the organism. Nitrosomonas europea is the most common species isolated from the wastewater treatment plants. The oxidation of ammonia leads to the formation of nitrite. Nitrite oxidation is affected principally by the members of genus Nitrobacter (N.agilis and N.wingogradskgi) and Nitrocystis. No intermediate products have been found in case of nitrite oxidation. The oxidation of nitrite leads to the formation of nitrate. Both Nitrosomonas and Nitrobacter are obligate aerobes but the absence of oxygen for a longer period is however, not lethal for them (Ford et al., 1980; Barnes and Bliss, 1983). McCartey et al., (1984) use activated sludge treatment for municipal wastewater which was subjected to lime treatment, air stripping recarbonation, filtration, granular activated carbon adsorption, reverse osmosis and chlorination. The water produced by this process was of high quality. It is with this aim the present research envisaged to determine the biosimulator performance for the removal of $\mathrm{COD}, \mathrm{NH}_{3}-\mathrm{N}, \mathrm{NO}_{2}-\mathrm{N}$ and $\mathrm{NO}_{3}-\mathrm{N}$ from the raw domestic wastewater during activated sludge treatment system and also to further confirm that primary treatment of wastewater further improves the performance efficacy of the activated sludge treatment system.

\section{MATERIALS AND METHODS}

Sample collection: The source for the collection of wastewater samples throughout the present studies was the pilot plant at the Karachi University Campus (KUC) Pakistan. Grab samples of mixed liquor were collected at the time of pumping of wastewater from the influent sump into the service tank. During the collection every attempt was made to avoid the collection of debris, papers, twigs as well as silt. The wastewater must be homogenous and smooth in consistency before it is processed. 
Primary treatment (Settleability): Imhoff cones were used for the primary treatment of wastewater samples. The samples collected were poured in $1 \mathrm{~L}$ imhoff cones and left for 30 minutes for primary sedimentation

Description of the wastewater treatment process: The technical details and the general layout of the biosimulator are shown in Table 1 and Figure 2

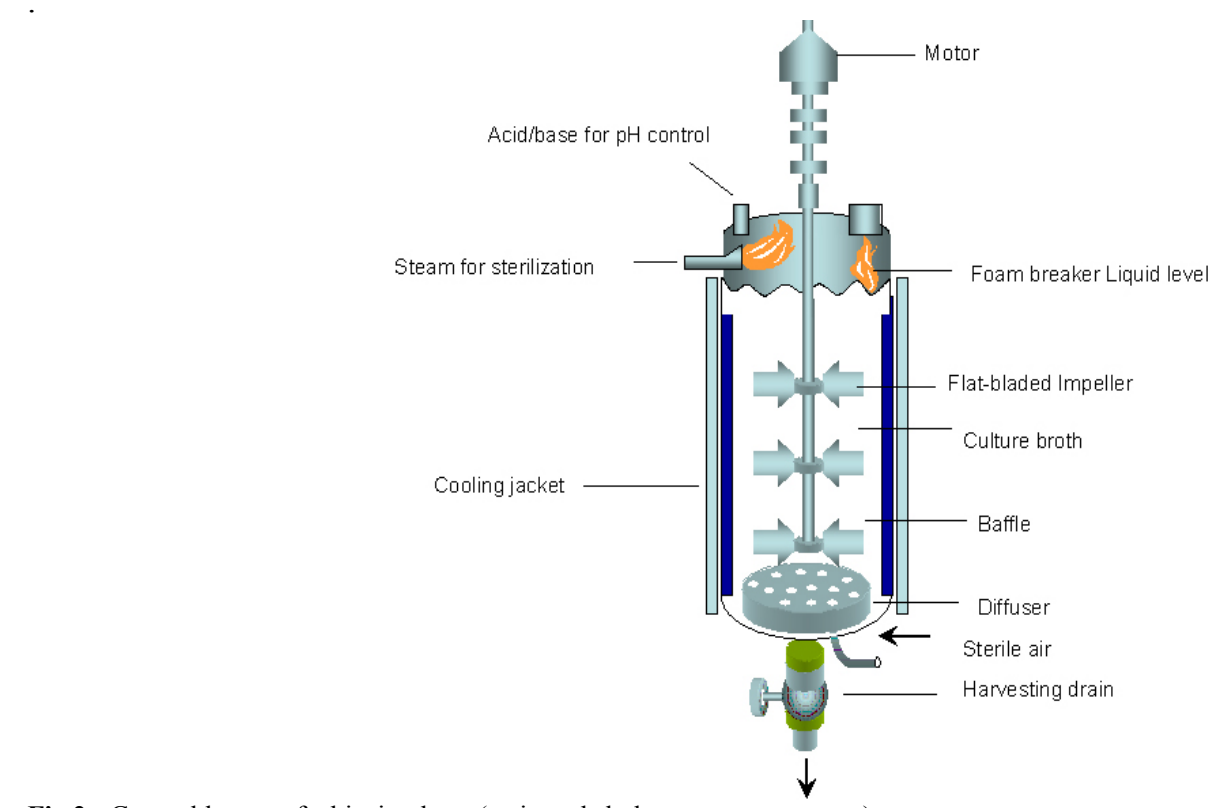

Fig 2 : General layout of a biosimulator (activated sludge treatment system)

Approximately 8.0 liters of sample was transferred carefully into the heavy wall, borosilicate glass jar of a compact bench scale stainless steel biosimulator (model MF-114). The sample was strongly agitated by impeller with flat stirring paddles and by the four vertical baffles. Agitation was continuously monitored on a calibrated electrical tachometer, which provides accurate speed indication. The required concentration of dissolved oxygen was achieved by using a pressure pump which was regulated through dissolved oxygen controller (model DO-81). Air was metered through a pressure regulator, needle valve flow meter and a stainless steel filter. The sample thus treated in the biosimulator with the preset DO concentration (Table 1).

Table 1. Technical Data of biosimulator General details

\begin{tabular}{|c|c|c|}
\hline 1. & Biosimulator & Model MF-114 \\
\hline & DO-Controller & Model DO-81 \\
\hline & pH-Controller & Model pH-22 \\
\hline 2. & Vessel capacity & 14-litres \\
\hline 3. & $\begin{array}{l}\text { Total volumetric load* } \\
\text { (raw wastewater) }\end{array}$ & 8-litres \\
\hline 4. & Retention time & 29 hours \\
\hline 5. & Operating Temperature & Ambient \\
\hline 6. & DO-concentration & $4.0 \mathrm{mg} / \mathrm{L}$ \\
\hline 8. & Sample collection & 1-hour \\
\hline
\end{tabular}

Processing of samples: The samples were collected from the biosimulator vessel after every two hours and were analyzed for settleability, chemical oxygen demand (COD; dichromate reflux method using HACH-COD reactor), ammonia-nitrogen $\left(\mathrm{NH}_{3}-\mathrm{N}\right)$, nitrite-nitrogen $\left(\mathrm{NO}_{2}-\mathrm{N}\right)$ and nitrate-nitrogen $\left(\mathrm{NO}_{3}\right.$ $\mathrm{N})$ as per methods described in the Standard Methods (1985) and US-EPA (1974). pH was measured by HASHMI IMRAN using automatic $\mathrm{pH}$ controller (model pH-22; New Brunswick Scientific Company) whereas dissolved oxygen (DO) was monitored by using automatic DO controller (model DO-81; New Brunswick Scientific Company).

\section{RESULTS AND DISCUSSION}

Biosimulator performance was evaluated after every 
2-hour and the samples were analyzed for $\mathrm{pH}, \mathrm{DO}$, $\mathrm{COD}$, ammonia-nitrogen $\left(\mathrm{NH}_{3}-\mathrm{N}\right)$, nitrite-nitrogen $\left(\mathrm{NO}_{2}-\mathrm{N}\right)$ and nitrate-nitrogen $\left(\mathrm{NO}_{3}-\mathrm{N}\right)$. In all ten experimental replicates were performed during the course of study and the mean figures are presented and discussed.

\section{Physical performance}

$\mathrm{pH}$ : During time course of activated sludge treatment there was a gradual increase in $\mathrm{pH}$ from 6.81 in the beginning to a maximum of 7.52 after 29 hours. The $\mathrm{pH}$ changes during activated sludge treatment of the wastewater in the biosimulator are shown in Table 3 and illustrated in Figure 3. Optimum $\mathrm{pH}$ for nitrification appears to be in the range of 7.5-9.0 (Barnes and Bliss, 1983). However, the $\mathrm{pH}$ towards 10 is detrimental for the heterotrophic bacteria that play a major role in wastewater treatment (Mayo and Noike, 1996). The trend of the $\mathrm{pH}$ was towards alkaline side. The $\mathrm{pH}$ also has a significant effect on the growth rate of Nitrosomonas and Nitrobacter (Wong-Chong and Loehr, 1975).

Settleability: During primary sedimentation in imhoff cones the overall mean percent settleability of ten experimental replicates were found to be ranging between $79-100 \%$, which also indicate that the activated sludge treatment system was quite efficient in reducing the Settleable solids content during the 29 hours detention time.

Chemical performance: Dissolved oxygen (DO): In the present study the DO was maintained at $4.0 \mathrm{mg} / \mathrm{L}$ because it has been shown capable to maintain aerobic conditions at the floc center (Kenneth and Peter, 1981). Very slight variation in dissolved oxygen concentration was observed and it was more or less the same as adjusted prior to the treatment. At this level of DO the performance of the system especially with reference to $\mathrm{COD}$ removal, changes in nitrogenous compounds $\left(\mathrm{NH}_{3}-\mathrm{N}, \mathrm{NO}_{2}-\mathrm{N}\right.$ and $\mathrm{NO}_{3}-$ $\mathrm{N})$ was evaluated. The initial DO of the raw wastewater was found to vary between 1.5 to 2.6 $\mathrm{mg} / \mathrm{L}$ (Table 2). The stability and efficiency of the activated sludge system depends upon the availability of oxygen. Two major processes affect the oxygen levels in the activated sludge system, one, and oxygen consumption by microbial respiration and second rate of oxygen input through mechanical means. The oxygen is utilized by microorganisms to degrade the organic matter and yield compounds for cell synthesis. The maintenance of a permanently oxygenated environment in the activated sludge system depends upon a positively balanced equilibrium between respiration (consumption) and oxygen input through mechanical means (Abeliovich and Vonshak, 1993). In practice, the DO in the aeration tank should be maintained at about 1.5-4.0 $\mathrm{mg} / \mathrm{L}$; values above $4.0 \mathrm{mg} / \mathrm{L}$ do not improve operations significantly, but increases the aeration costs considerably (Dae-Sung and Heekyung, 1998). Dissolved oxygen is also known to have an important influence on nitrification rates in the wastewater treatment systems. The uptake of inorganic carbon by nitrifiers has been found to be affected by dissolved oxygen concentration. It is reported to be one of the absolute growth requirements for both Nitrosomonas and Nitrobacter (Gujer and Jenkins, 1974). Oxygen is involved in ammonia oxidation not only by incorporation into the energy substrate but also involved in electron transport chain. The value attributed to oxygen half saturation coefficient ranged from 0.3-2.0 $\mathrm{mg} / \mathrm{L}$. This suggested range was probably due to the fact that concentration of DO in the bulk liquid is not necessarily the same as inside the biological floc where the oxygen consumption takes place (WRC, 1984). There is evidence that higher DO concentration of $3-4 \mathrm{mg} / \mathrm{L}$ can significantly enhance nitrification efficiency (Benefield and Randall, 1980). But Bliss et al., (1981) found relatively little further improvement at $5-6 \mathrm{mg} / \mathrm{L}$ DO. At $<2.0 \mathrm{mg} / \mathrm{L}$ DO the process of denitrification was found to prevail (Wong-Chong and Loehr, 1975). Moreover, the nitrifying bacteria are slow growers than heterotrophic bacteria, which comprise the greater population of the biomass in both fixed film and suspended growth systems. These heterotrophic bacteria include Pseudomonas, Achromobacter, Bacillus and Micrococcus that cause denitrification (Wuhrmann, 1964). It is reported that nitrification can be achieved in an activated sludge process provided that the net growth of the nitrifying bacteria must not be less than the net growth rate of the biomass in the system (Eckenfelder, 1989). 

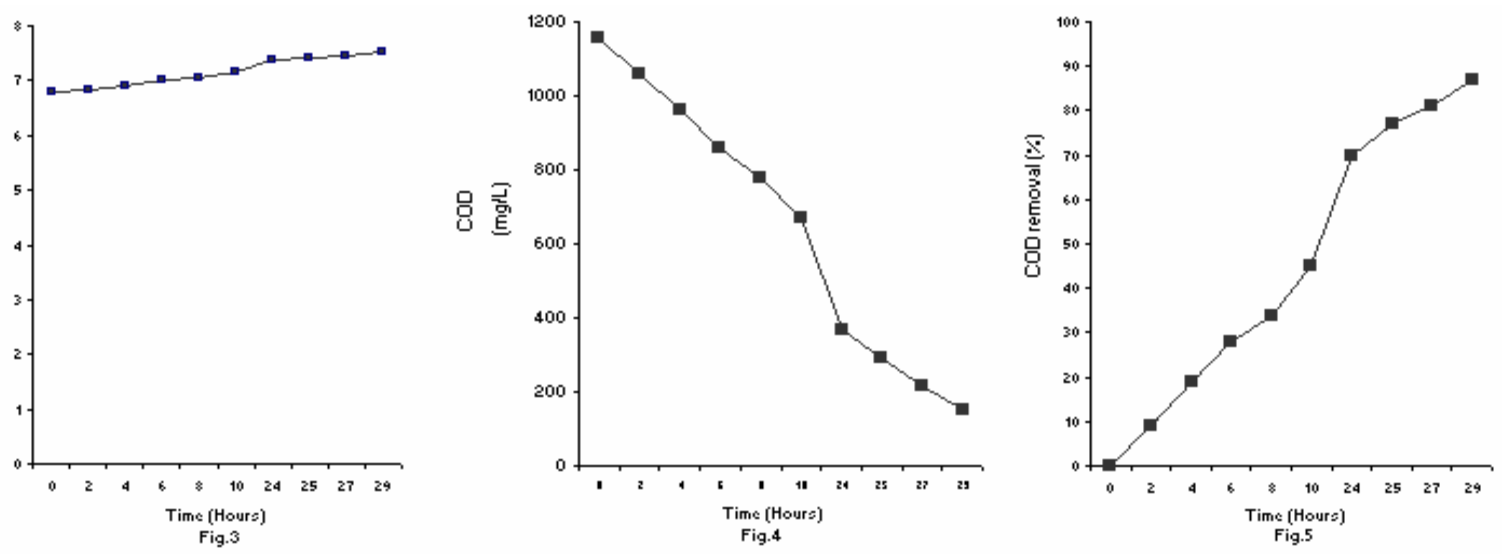

Fig 3-5: Performance evaluation of biosimulator (activated sludge treatment system) at $4.0 \mathrm{mg} / \mathrm{L} \mathrm{DO}$ [Fig.3. Changes in pH values; Fig.4. Residual COD values; Fig.5. COD (5) removal efficiency]

Chemical oxygen demand (COD): The COD results are reported in Table 3 and illustrated in Figure 4. The mean COD values of the treated samples were found to be ranging between $164-1160 \mathrm{mg} / \mathrm{L}$ with mean removal efficiency of $87 \%$ after 29 hours of treatment. Polprasert et al. (1992) reported that with the increase in organic loading COD removal efficiency also increased. From the results reported in Table 4 it is seen that the COD of the samples gradually decreased. Toprak (1995) reported that COD removal was not only a function of the hydraulic retention time and concomitant organic loading rate but also influenced by the influent COD concentration and temperature. Ahmed et al. (1988) also reported that COD removal increased with the retention time. The COD removal rate looks quite consistent with time. At 2 hours the removal efficiency was $9 \%$, at 4 hours it was $19 \%$, that is an additional $10 \%$ COD was removed within a further 2 hours detention time. The COD removal efficiency was linear in the first 10 hours of treatment. It was also linear from 24-29 hours but of a slight lower order. The COD removal seems proportional to the microbial cell density in the log phase. Better COD removal efficiency would be observed when the cells are in the $\log$ phase of growth. Barker and Dold (1995) also observed good COD and nitrogen balances on different types of laboratory scale activated sludge system.

Ammonia, nitrite and nitrate nitrogen $\left(\mathrm{NH}_{3}-\mathrm{N}, \mathrm{NO}_{2}-\right.$ $\mathrm{N} \& \mathrm{NO}_{3}-\mathrm{N}$ ): Nitrogen in domestic sewage is present in the form of ammonium (about $60 \%$ ) and $40 \%$ as organic nitrogen (Barnes and Bliss, 1983). The results of $\mathrm{NH}_{3}-\mathrm{N}$ were not consistent as that of COD (Table 3). The increase in $\mathrm{NH}_{3}-\mathrm{N}$ content indicates that might be the concentration of DO was not up to the mark. The residual $\mathrm{NH}_{3}-\mathrm{N}$ was still very high which is generally considered to be due to decreased nitrification activity responsible for converting $\mathrm{NH}_{3}$ HASHMI IMRAN
$\mathrm{N}$ to $\mathrm{NO}_{3}-\mathrm{N}$.

In the present study (Table 3 and Figure 6) the $\mathrm{NH}_{3}-\mathrm{N}$ removal rate was not significant. A mean removal efficiency of $29 \%$ was observed. It is difficult to account for this behavior in view of lack of more data. However, it may be that heterotrophic bacterial activity was more pronounced as compared to autotrophic bacterial activity that is responsible for $\mathrm{NH}_{3}-\mathrm{N}$ conversion into nitrate through nitrification process. It is suggested to study heterotrophic and autotrophic bacterial activity relationship in the activated sludge treatment process especially in the presence of different sources of organic carbon (Barnes and Bliss, 1983). In activated sludge system nitrogen is found as soluble ammonia and as particulate and dissolved organic nitrogen. Ammonia is produced by the hydrolysis of urea and by the biological degradation of organic compounds, such as amino acids mainly through the deamination process in the presence of oxygen. Ammonia is found in equilibrium between the molecular gaseous form and the ionic form. This reaction is highly dependent on $\mathrm{pH}$ and temperature. Alkaline $\mathrm{pH}$ and higher temperature favors the molecular form whereas neutral and acidic $\mathrm{pH}$ favors the presence of ionic forms (Idelovitch and Michail, 1981). The rate of nitrification in the activated sludge system also depends upon the temperature and oxygen availability. Ammonia is oxidized to nitrite and then finally to nitrate which serves as an electron acceptor for the facultative heterotrophic bacteria so that aerobic metabolism can proceed. The metastable nitrite is seldom found and the final product of nitrification is nitrate (Alleman and Irvine, 1980). The decreased $\mathrm{NH}_{3}-\mathrm{N}$ removal efficiency might be due to high organic load. High $\mathrm{NH}_{3}-\mathrm{N}$ concentration in the treated effluent is generally considered to be due to decreased nitrification activity, which is responsible for converting $\mathrm{NH}_{3}-\mathrm{N}$ to $\mathrm{NO}_{3}-\mathrm{N}$ (Abeliovich and Vonshak, 1993). However the 
optimal $\mathrm{pH}$ for nitrite and nitrate forming bacteria is alkaline and is not sharply defined. There is marked decrease in nitrification at a temperature below $18^{\circ} \mathrm{C}$ and above $35^{\circ} \mathrm{C}$. The optimal $\mathrm{pH}$ for nitrification ranges from 7.5 to 9.0 (Barnes and Bliss, 1983). It is also reported that free ammonia rather than the oxidized ammonia is a substrate for Nitrosomonas and nitrous acid is the substrate for Nitrobacter (Gearheart, 1992; Ford et al., 1980).

Another reason of decreased $\mathrm{NH}_{3}-\mathrm{N}$ removal efficiency was the $\mathrm{pH}$ during the entire period of the study. $\mathrm{NH}_{3}-\mathrm{N}$ removal is more pronounced within a $\mathrm{pH}$ range of $8-9$, but the combination of ammonia concentration of $>2.0 \mathrm{mM}$ and the $\mathrm{pH}$ value of 8.18.2 is strongly inhibitory leading to poor oxygenation and development of anoxic conditions (Abeliovich and Vonshak, 1993). Concentration of 1-5 mg/ $\mathrm{L} \mathrm{NH}_{3}^{-}$ $\mathrm{N}$ inhibits nitritation but not nitration (Abeling and Seyfried, 1992). In the present study both $\mathrm{pH}$ values and DO concentration $(4.0 \mathrm{mg} / \mathrm{L})$ are optimum for the process of nitrification to occur at enhanced rate whereas the $\mathrm{NH}_{3}-\mathrm{N}$ removal seems to be affected by retention time which may be one of the possible reasons for increased $\mathrm{NH}_{3}-\mathrm{N}$ concentration in the treated effluent. Furthermore high $\mathrm{NH}_{3}-\mathrm{N}$ concentration would possibly be due to high organic load that could not be degraded completely by the microorganisms in the present study. It is also reported that the process of nitrification is inhibited by high concentration of free nitrous acid between $0.22-2.8 \mathrm{mg} / \mathrm{L}$ (Eckenfelder, 1989). Since the process of nitrification is dependent on temperature and oxygen availability, it could be seen from Table 3 that conversion of $\mathrm{NH}_{3}-\mathrm{N}$ to $\mathrm{NO}_{2}$ and then finally to $\mathrm{NO}_{3}$ was very low. This could be due to high organic loading and low retention time. Moreover, the rate of ammonia oxidation depends upon the population of nitrifying bacteria in the sludge and their growth rate under the conditions prevailing in the aeration tank. The low conversion of $\mathrm{NH}_{3}-\mathrm{N}$ in the present study may be due to the lesser number of nitrifying bacteria as has also been described by Barnes and Bliss (1983). Eckenfelder (1989) proposed a specific

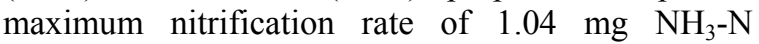
oxidized per milligram of nitrifying microbial mass per day.
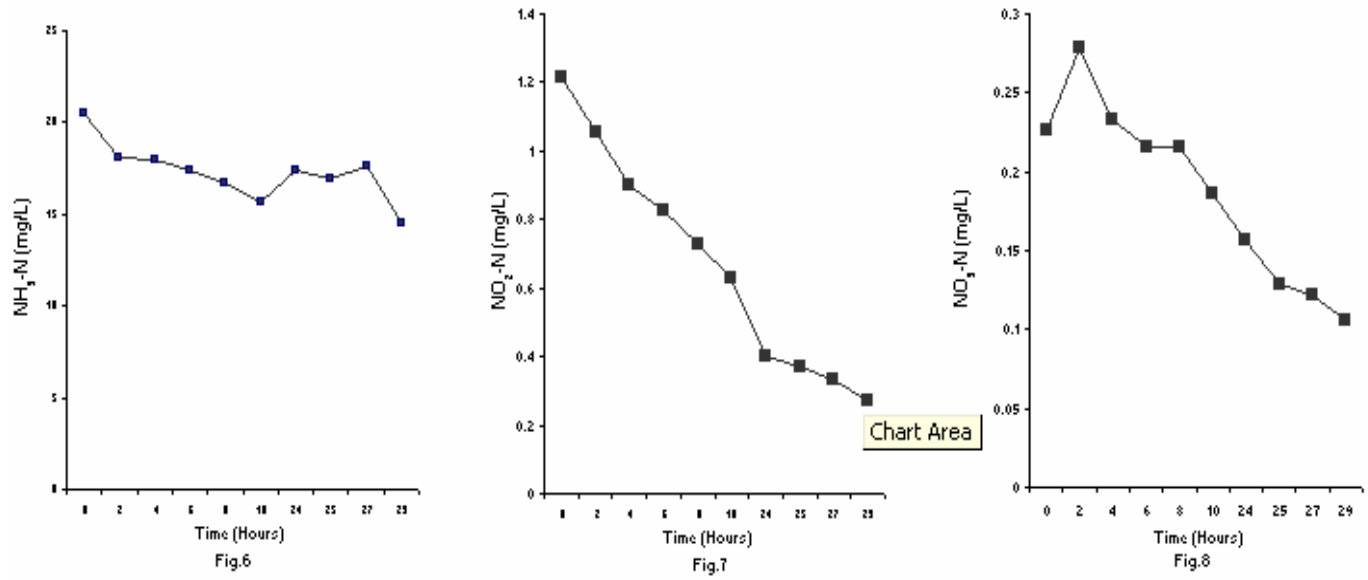

Fig 6-8: Performance evaluation of biosimulator (activated sludge treatment system) at $4.0 \mathrm{mg} / \mathrm{L}$ DO [Fig.6. $\mathrm{NH}_{3}-\mathrm{N}$ (mg/L); Fig.7. $\mathrm{NO}_{2}-\mathrm{N}$ $(\mathrm{mg} / \mathrm{L}) ;$ Fig. $\left.8 . \mathrm{NO}_{3}-\mathrm{N}(\mathrm{mg} / \mathrm{L})\right]$

The mean results of $\mathrm{NO}_{2}-\mathrm{N}$ were consistent throughout the study period. Similarly the mean results of $\mathrm{NO}_{3}-\mathrm{N}$ are reported in Table 3 and illustrated in Figure 8. Except for the initial increase of $\mathrm{NO}_{3}-\mathrm{N}$ in the first 2 hours of treatment there was a persistent rate of $\mathrm{NO}_{3}-\mathrm{N}$ removal which continued up to 29 hours of treatment. $53 \%$ removal rate was observed at 29 hours (end of experiment). $\mathrm{NO}_{3}-\mathrm{N}$ removal indicates that nitrogen is being assimilated for the formation of biomass. Nitrification rates in wastewater depend upon the dissolved oxygen concentration. Many workers have suggested an optimum DO concentration of 2 to $3 \mathrm{mg} / \mathrm{L}$, together with a BOD of less than $20 \mathrm{mg} / \mathrm{L}$ and COD of 30-40 $\mathrm{mg} / \mathrm{L}$ was needed for nitrification to occur (WongChong and Loehr, 1975; Eckenfelder, 1989; Barnes and Bliss, 1983). The low $\mathrm{NO}_{3}-\mathrm{N}$ concentration indicates that concentration of dissolved oxygen was not up to the mark where rapid conversion of $\mathrm{NH}_{3}-\mathrm{N}$ occurs. The low concentration of $\mathrm{NO}_{3}-\mathrm{N}$ would also indicate the development of anoxic condition. However, the system was not completely anaerobic.

Conclusion: In the present study the dissolved 
oxygen concentration was maintained at $4.0 \mathrm{mg} / \mathrm{L}$ and at this concentration the biosimulator performance was found to be satisfactory. This concentration of oxygen was adequate enough without being aesthetic nuisances to maintain aerobic conditions throughout the entire system and the quality of effluent being obtained after treatment was acceptable for landscape irrigation and for growing plants of ornamental value for commercial use. Activated sludge treatment system technology produces an effluent of a quality that is relatively safer to use from the public health point of view. In areas where there is scarcity of water great emphasis has been given to use reclaimed water from the activated sludge treatment system. Further the availability of irrigation water at a reasonable cost is one of the important factors, which affects the development and expansion of agriculture in the arid and semi arid regions of the world. As observed while working in biosimulator, the $\mathrm{NH}_{3}-\mathrm{N}$ production and removal was erratic, this may perhaps be due to variable heterotrophic and autotrophic bacterial activity. The residual $\mathrm{NH}_{3}-\mathrm{N}$ was still very high which is generally considered to be due to decreased nitrification activity responsible for converting $\mathrm{NH}_{3}$ $\mathrm{N}$ to $\mathrm{NO}_{3}-\mathrm{N}$. Ammonia removal efficiency is directly proportional to retention time. Increasing concentration of DO would mean wastage of resource and material, thus making the system uneconomical. Further research is going on this aspect to upgrade the performance efficiency of biosimulator.

Acknowledgement: The thoughtful comments and suggestions received from colleagues are highly appreciated. We gratefully acknowledge the financial support of University of Karachi, Pakistan to carry out this research.

\section{REFERENCES}

Abeling, U. and Seyfried, C. F. (1992). Anaerobic Aerobic treatment of high-strength ammonium wastewater-nitrogen removal via nitrite. Wat. Sci. Tech. 26 (5-6): 1007-1015.

Abeliovich, A. and Vonshak, A. (1993). Factors inhibiting nitrification of ammonia in deep wastewater reservoirs. Wat. Res. 27 (10): 15851590.

Ahmed, K.; Aziz, J. A.; Tariq, M. N. and Malik, A. M. (1988). A laboratory study of the performance of anaerobic waste stabilization ponds. Sci. Tech. and Develop. 7 (4): 15-22.

Alleman, J. E. and Irvine, R. L. (1980). Nitrification in the sequencing batch biological reactor. Jour. W. P. C. F. 52 (11): 2747-2754.

HASHMI IMRAN
Barker, P. S. and Dold, P. L. (1995). COD and nitrogen mass balances in activated sludge systems. Wat. Res. 29 (2): 633-643.

Barnes, D. and Bliss, P. J. (1983). Biological Control of Nitrogen in Wastewater Treatment. E. and F. N. Spon. Ltd. London.

Benefield, L. D. and Randall, C. W. (1980). Biological Process design for wastewater treatment. Prentice-Hall, Englewood Cliffs, New Jersey.

Bliss, P. J.; Barnes, D. and Windschuttel, B. A. (1981). In : Proc. Ninth Federal Conv. Australian Water Wastewater Assoc., Perth, April, 7/1-12.

Cakici, A. and Bayramoglu, M. (1995). An approach to controlling sludge age in the activated sludge process. Wat. Res. 29 (4): 1093-1097.

Dae-Sung, J. and Heekyung, P. (1998). Control of the dissolved oxygen concentration in the activated sludge process. Environ. Eng. Res. 3 (2):115121.

Eckenfelder, W. W. (1989). Industrial Water Pollution Control. McGraw-Hill. New York.

Eliosov, B. and Argaman, Y. (1995). Hydrolysis of particulate organics in activated sludge systems. Wat. Res. 29 (1): 155-163.

Ford, D. L.; Churchwell, R. L. and Kachtick, J. W. (1980). Comprehensive analysis of nitrification of chemical processing wastewater. J.W.P.C.F. 52 (11):2736-2746.

Gearheart, R. A. (1992). Use of constructed wetlands to treat domestic wastewater, City of Arcata, California. Wat. Sci. Tech. 26 (7-8): 1625-1637.

Gujer, W. and Jenkins, D. (1974). The contact stabilization process. Oxygen and nitrogen mass balances. Sanitary Engineering Research Laboratory Report No. 74-2. University of California, Berkeley.

Henze, M.; Grady, C. P. L. Jr.; Gujer, W.; Marais, G. U. R.; Matsoo, T. (1987). A general model for single sludge wastewater treatment system. Wat.Res. 21 (5): 505-515.

Idelovitch, E. and Michail, M. (1981). Nitrogen removal by free ammonia stripping from high pH ponds. Jour. W. P. C. F. 53 (9):1355-1440. 
Kenneth, J. W. and Peter, O. N. (1981). Influence of dissolved oxygen on activated sludge viability. Journ. W. P. C. F. 53 (10): 1533-1540.

Lumbers, J. P. (1984). Effluent reuse. Course on Waste Stabilization Ponds Designs and Operation. Organized by NED University of Engineering and Technology, Karachi. Pakistan, in collaboration with World Health Organization.

Mara, D. (1978). Sewage Treatment in Hot Climates. John Wiley and Sons, Inc. New York.

Mayo, A. W. and Noike, T. (1996). Effects of temperature and $\mathrm{pH}$ on the growth of the heterotrophic bacteria in waste stabilization ponds. Wat. Res. 30 (2): 447-455.

McCarty, P. L.; Reinhard, M.; Goodman, N. L.; Graydon, J. W.; Hopkins, G. D.; Mortelmans, K. E. and Argo, D. G. (1984). Advanced treatment for wastewater reclamation at water factory 21 . Project summary, EPA-600/S2-84-031. Municipal Environmental Research Laboratory, Cincinnati. OH. 45268.

Muller, C. M.; Gujer, W. Giger, W. and Stumn, W. (1980). Non-biological elimination mechanisms in a biological sewage treatment plant. Prog. Water. Tech. 12: 299-314.

Nicholas, L. (1989). The Ocean Blues. World Watch Institute. World Watch. 2 (4):26.

Polprasert, C.; Kessomboon, S. and Kanjanaprapin, W. (1992). Pig wastewater treatment in water hyacinth ponds. Wat. Sci. Tech. 26 (9-11): 23812384.
Ramalho, S. R. (1977). Introduction to Wastewater Treatment Processes. Laval University Quebec, Canada. Academic Press, New York.

Robert, A. M. (1998). Encyclopedia of Environmental Analysis and Remediation. 8. A Wiley Encyclopedia Series in Environmental Science. John Wiley and Sons, Inc. New York.

Sezgin, M. (1980). The role of filamentous microorganisms in activated sludge settling. Prog. Wat. Tech. 12:97-107.

Standard Methods for the Examination of water and wastewater (1985). 16 $6^{\text {th }}$ Edit. American Public Health Association (APHA), Water Pollution Control Federation (WPCF), American Water Work Association (AWWA).

Toprak, H. (1995). Removal of soluble chemical oxygen demand from domestic waste waters in a laboratory scale anaerobic waste stabilization ponds. Wat. Res. 29 (3): 923-932.

US-EPA. (1974). Methods for the chemical analysis of water and wastes. US-EPA-625/6-74-003. Office of Technology Transfer, Washington DC.

Wong-Chong, G. M. and Loehr, R. C. (1975). The kinetics of microbial nitrification. Wat. Res. 9: 1099.

WRIR (World Resource Institute Report ). (1990). Oceans and Coasts. 22, 179.

WRC (1984). Theory, design and operation of nutrient removal activated sludge processes. Water Research Commission of South Africa, South Africa.

Wuhrmann, K. (1964). Nitrogen removal in sewage treatment processes. Verhandl. Inter. Verein. Limnol. XV. 580 